\title{
A crítica de Nietzsche à moral da compaixão de Schopenhauer em Aurora: o desprezo de si como artimanha de condenação do indivíduo
}

\author{
Jelson Roberto de Oliveira \\ Doutor em Filosofia. Professor do programa de pós-graduação (mestrado) em Filosofia da \\ PUCPR. Membro do GPN-PUCPR (Grupo de Pesquisa Nietzsche).
}

RESUMO: Pretende-se analisar a crítica de Nietzsche à moral da compaixão no que tange ao critério de negação de si como seu fundamento. Centrar-se-á, nesse artigo, nos dois primeiros livros de Aurora, obra que forma o chamado segundo período do pensamento nietzschiano e que, nessa perspectiva, é parte do processo de rompimento e distanciamento em relação à filosofia schopenhauriana.

PALAVRAS-CHAVE: Eu; desprezo de si; egoísmo; compaixão; amor ao próximo.

ABSTRACT: In this article we intend to analyze Nietzsche's critique of the morality of compassion in relation to the criterion of self-denial as its foundation. We will focus in this text, the first two books of Daybreak, work that forms the second period of Nietzschean thought and is part of the process of breaking away and distancing itself from the Schopenhauerian philosophy.

KEYWORDS: self; self-contempt; egoism; compassion; love of neighbor.

\section{Introdução}

Nos escritos que formam o chamado "período intermediário" ou "segundo período" da obra de Nietzsche (1876-1882) se consolidam como momento em que o filósofo explicita a sua intenção de ruptura em relação às teorias schopenhaurianas. Um dos motes principais dessa tentativa de distanciamento diz respeito ao problema do desprezo de si, identificado por Nietzsche como a base principal da moral da compaixão e, consequentemente, como um ardil para a condenação do indivíduo. Para o autor de Aurora Schopenhauer, como "ante-sala do cristianismo" (KSA 8, 30 [9], de 1878, p. 523) ², segue à risca essa tendência basilar de toda a moral ocidental, cuja referência, em última instância, é o imperativo representado pelo mandamento bíblico do amor ao próximo o qual está, desde a tradição antiga, associado à negação ou esquecimento de si: "O mais antigo que sobre o homem se pensou se oculta na famosa máxima: 'o eu sempre é odioso' [Pascal, Pensamentos, A, 79]; o mais jovem, na ainda mais famosa: 'ama a teu próximo como a ti mesmo' [Levítico 19, 18]. Numa, o conhecimento do homem cessou; na outra, nem começou ainda". (OS, 385). Para Nietzsche o amor a si mesmo ainda não começou a ser praticado pelo cristianismo como condição do amor ao próximo, já que a velha máxima pascaliana continua tendo mais força do que a levítica. O que o filósofo alemão acentua nesse fragmento é que o ódio ao "eu” aparece como empecilho para o verdadeiro amor, 
porque, no fundo, para ele, todo amor tem como base o amor a si. O "ódio ao eu" frequentemente pronunciado como regra da moral da compaixão, seria, segundo Nietzsche, a mais contundente contraposição ao amor ao próximo, já que quem não ama a si mesmo não deveria ter motivos para ser amado pelos outros. No $\S 79$ de Aurora o filósofo pergunta: "Se nosso Eu, conforme Pascal e o cristianismo, é sempre odiável, como poderíamos supor e admitir que outros o amem - seja Deus ou homem! Seria contrário a toda decência, fazer-se amar sabendo muito bem que merece apenas ódio”. A moral da compaixão carregaria, na sua base, a negação da sua própria possibilidade, porque a negação daquilo que Nietzsche nessas passagens chama de "eu" impossibilita a identificação com o próximo, já que ele é alguém que não se ama.

Essa é, para o filósofo, a posição tanto do Cristianismo quanto do próprio Schopenhauer. Nietzsche entende a proposição moral do filósofo de Frankfurt como um resultado perfeitamente acabado da tentativa de fuga da existência, marcada pela dor que advém do egoísmo que faz todo homem e toda ação humana ser motivada pelo interesse próprio: "cada indivíduo, que desaparece por completo e diminui ao nada em face do mundo sem limites, faz, no entanto de si mesmo o centro do universo" (MVR, p. 426). O egoísmo, assim, seria a força mobilizadora do indivíduo porque ele antepõe "a própria existência e o bem-estar a tudo o mais, sim, do ponto de vista natural está preparado a sacrificar qualquer coisa, até mesmo a aniquilar o mundo, simplesmente para conservar mais um pouco o próprio si-mesmo, esta gota no meio do oceano" (MVR, p. 427). Essa posição egoísta e interesseira está posicionada na essência mesma do homem como animal e só a experiência moral poderia, segundo Schopenhauer, romper com esse processo, porque ela possibilita a escolha entre a bondade e a maldade. Contra o móvel moral do egoísmo e da maldade, o filósofo estabelece então, a fórmula da piedade: ajudar aos outros e não fazer-lhes mal aparece como a fórmula da moral da compaixão, a participação no sofrimento do outro como processo de purificação que tem o seu auge na libertação do sofrimento do mundo através da mais radical renúncia ao querer-viver - a emancipação da vontade. Para Schopenhauer, a "fonte última" da maldade "é um elevadíssimo grau de egoísmo" porque "numa tal pessoa exprime-se uma vontade de vida veemente ao extremo" e ela passa a procurar "apenas o próprio bem-estar, totalmente indiferente ao dos outros" (MVR, p. 462). Para ele, essas características "são os elementos básicos do mau caráter" (MVR, p. 463) e, portanto, a fonte de toda a maldade. Para Nietzsche, isso representaria, sem dúvida, a negação do próprio ser do homem, o desejar mal para si como móvel ético porque só negando a si mesmo seria possível tornar-se moral, segundo o modelo da compaixão. 
Nietzsche tem em vista, portanto, a crítica à ideia schopenhauriana de "boa consciência" (MVR, p. 475), que é o resultado de uma "satisfação sentida após cada ato desinteressado" que derivaria do "reconhecimento imediato da nossa própria essência em si no fenômeno de outrem", ou seja, que o eu precisa diluir-se em tudo para que reconheça a si em tudo (e não apenas em si mesmo) e, assim, seja capaz de agir desinteressadamente: “que o verdadeiro eu não existe apenas na própria pessoa, este fenômeno individual, mas em tudo o que vive" (MVR, p. 475). É o conhecimento ou o reconhecimento da essência geral do mundo como Vontade que faz cada indivíduo estender a sua simpatia para com os demais seres vivos, dilatando o seu coração em direção ao outro. Enquanto o homem egoísta vive contraído e acuado, o homem compassivo tem seu coração tranqüilo e leve: "O egoísta sente-se acuado por fenômenos estranhos e hostis e toda a sua esperança repousa sobre seu bem-estar. O homem bom, ao contrário, vive num mundo de fenômenos amigáveis: o bem-estar de cada um destes é seu próprio bem-estar" (MVR, p. 475). Nessa perspectiva, Schopenhauer conclui com a sentença amplamente combatida por Nietzsche: "Todo amor (ágape, caritas) é compaixão" (MVR, p. 475). Isso significa que só pela anulação de si o homem poderia falar realmente de amor - no sentido de um afeto puro e desinteressado que "iguala por completo o indivíduo estrangeiro com seu destino ao próprio indivíduo" (MVR, p. 476), o que significa que esse amor é a fonte da igualdade, pela substituição do amor próprio pelo amor ao próximo.

$\mathrm{O}$ que Nietzsche pretende mostrar é que esse ódio ao eu teria como resultado também o ódio ao outro. Os dois livros iniciais de Aurora, em especial, tem como objetivo o desvendamento dessa "artimanha".

\section{O “eu" como opinião errada do homem sobre si mesmo}

A negação do $e u$ está baseada, segundo Nietzsche, na ideia de que ele [o $e u$ ] se trata de algo carregado das paixões e impulsos corporais negados porque antes são temidos. Como forma de fuga desse lado considerado sombrio ou negativo, o eu passa a ser identificado como uma sustância metafísica e consciente (a alma, por exemplo), totalmente imaterial e, portanto, preservado numa instância não contaminada pelos impulsos corporais. O eu que se nega é o eu que tem desejos, interesses e impulsos. Ele precisa ser anulado porque o egoísmo não pode ser admitido. O ideal da alma é que ela se entregue ao próximo, limite e anule os seus impulsos. Esse processo de negação do eu que é corpo teria, assim, como mote principal a criação da alma, da consciência e do sujeito (expressões do "eu"). Mas aquilo que se revela à nossa consciência e é captado pela linguagem como o que um indivíduo é são meras falsificações: "por essas manifestações grosseiras, as únicas que nos 
são conhecidas, nós nos conhecemos mal" (A, 115). O Eu não passa então, de uma opinião errada sobre nós mesmos, mas que vem a formar aquilo que a moral da compaixão chama de caráter. O tal "mundo do sujeito" não é senão um "mundo desconhecido" (A, 116), uma revelação da ignorância do humano sobre si mesmo.

É dessa base que nasce a crítica de Nietzsche ao desprezo de si, denunciado como uma "artimanha" utilizada pela moral da compaixão para condenar o indivíduo e o mundo e, de forma sagaz, impedir o desprezo pelo outro. O fragmento 3 [128] é expressivo nesse sentido ao ligar o cristianismo ao "excesso de moralidade oriental" trazida pelos judeus à Europa. O medo e o desprezo teriam adentrado o velho continente pelas mãos judaicas, pelas experiências doloridas vividas por esse povo no passado e que alimentaram entre seus indivíduos um mundo interior marcado pela "imaginação agitada, cobiçosa, fértil em revanches secretas, lugar fecundo daquela moralidade sublime e acusadora e daquele heroísmo selvagem, que se mostra tanto na abnegação perante seu comandante Deus quanto no desprezo por si mesmo" (KSA 9, 3 [128], de 1880, p. 88). Esse sentimento foi transferido, pela via da moral da compaixão, a toda a Europa, doando aos europeus "esse mal-estar judaico em si mesmo, a ideia da inquietação interna como normalidade humana: eis a razão da fuga dos europeus de si mesmos, eis a razão dessa atividade inaudita; eles colocam a cabeça e as mãos por toda parte". Ou seja, o autodesprezo, a necessidade de autonegação (tal como se apresentam no anacoreta e no monge citados por Nietzsche nesse fragmento) são os empecilhos para uma "vida superior". Ao contrário, os gregos não seriam formados desse tecido de inquietação interior: "quão tranquilos, quão cheios de si e de outras boas coisas eles parecem perto de nós! Não conheciam ninguém acima deles e não precisavam se menosprezar" (KSA 9, 3 [128], de 1880, p. 88).

Ao analisar o cristianismo em contraposição ao politeísmo grego, no parágrafo 143 de A Gaia Ciência, Nietzsche evoca esse aspecto nocivo do cristianismo que prevê uma ética do dever e da obediência à lei divina - fato que contribuiu para a hostilidade à criação da lei individual, ou seja, ao fato de que cada indivíduo deveria ser legislador de si mesmo:

Que o indivíduo estabelecesse seu próprio ideal e dele derivasse a sua lei, seus amigos e seus direitos - isso talvez fosse considerado, até então o mais monstruoso dos equívocos humanos e a idolatria em si (...) Ser hostil a esse impulso para um ideal próprio: tal era, então, a lei de toda moralidade. Havia apenas uma norma: "o homem" - e cada povo acreditava possuir essa única e derradeira norma. Mas além de si e fora de si, num remoto sobremundo, era permitido enxergar uma pluralidade de normas: um deus não era a negação ou a blasfêmia contra um outro deus! Aí se admitiu, pela primeira vez, o luxo de haver indivíduos, aí se honrou, pela primeira vez, o direito dos indivíduos. (GC, 143) 
Então, para Nietzsche, o desprezo de si é o estratagema (Kunstgriff) para fomentar o amor ao próximo, porque ele (1) dissipa o desprezo do outro com o desprezo de si mesmo e (2) ele traz uma consolação através do sentimento de igualdade que nasce desse desprezo (cada um é tão desprezível como todos os outros). É o que se lê no fragmento 117 de Humano, Demasiado Humano, intitulado Da inteligência do cristianismo:

É artimanha do cristianismo ensinar a total indignidade, pecaminosidade e abjeção do homem, em voz tão alta que o desprezo ao semelhante já não é possível. "Ele pode pecar quanto queira, contudo não se diferencia essencialmente de mim: eu é que sou, em todos os graus, indigno e abjeto", assim, diz o cristão. Mas mesmo esse sentimento perdeu seu aguilhão mais agudo, pois o cristão não crê em sua abjeção individual: ele é mau por ser homem simplesmente, e se tranquiliza um pouco dizendo: "Somos todos da mesma espécie”.

O resultado dessa artimanha é que o indivíduo, através desse sentimento de desprezo de si, acaba desprezando em si não o que lhe é próprio, mas justamente aquilo que lhe torna igual aos demais de sua espécie, ou seja, o fato mesmo de ser humano. Desprezando a si por essa condição, ele olha ao seu redor e ao invés de condenar o outro, vislumbra nele o sentimento de igualdade e identificação que impede o seu desprezo. O que se partilha, então, é a proximidade com o outro enquanto este se apresenta também indigno e desprezível. Paradoxalmente, o reconhecimento da condição humana como desprezível impede o desprezo do próximo (eis a artimanha) e torna igual ("todos da mesma espécie") justamente no motivo do desprezo.

\section{O desprezo de si impossibilita a compaixão}

Entretanto, esse argumento de Humano, demasiado humano ainda não evidencia uma mudança na arguição de Nietzsche e naquilo que ele apontará de incoerente nesse modelo, já que nos textos de Aurora se verá como o autor sublinha o fato de que esse desprezo de si é a base justamente do desprezo do próximo. A essa argüição a respeito da artimanha da ética da compaixão é acrescentada uma nova perspectiva: o desprezo de si impossibilita o amor ao próximo, porque, segundo a moral da compaixão, dever-se-ia olhar o outro como se olha para si mesmo. Ora, quem olha para si mesmo com desprezo, não pode ver o outro a não ser como também desprezível:

Supondo que sentíssemos o outro tal como ele sente a si próprio - o que Schopenhauer denomina compaixão [Mitleid - com-sofrimento; dor compartilhada], e que seria mais correto chamar de "unipaixão" [Ein-leid], "unidade na paixão" [Ein-leidigkeit] - teríamos que odiá-lo, se ele, como Pascal, considera-se odiável. E provavelmente é o que sentia Pascal em relação à humanidade como um todo, e também o antigo cristianismo, que foi "convicto", 
sob Nero, de odium generis humani [ódio ao gênero humano], como informa Tácito. (A, 63)

Esse ódio a si mesmo anunciado por Pascal e assumido por Schopenhauer seria então, para Nietzsche, o motivo que faz da ética da compaixão uma pseudoética: o argumento inviabilizaria o projeto schopenhauriano de uma compaixão (ou, no trocadilho de Nietzsche, que pretende destacar a ideia de que se trata de um mesmo sentimento de dor, portanto, de uma "unipaixão"), já que esse sentimento brota de um ódio a si mesmo. É nisso que se revela a "indecência" desse tipo de sentimento - pretende-se que os outros amem aquilo que nem nós mesmos amamos (cf. A, 79)

A argumentação de Nietzsche nesse parágrafo (cujo título é Uma sugestão) levaria à supressão da própria base da moralidade compassiva: se se requer o amor ao outro como uma "graça", então ele deveria ser usado como pretexto também para o amor de si mesmo. Ora, se o desprezo de si está legitimado na engenhosidade argumentativa da ética compassiva (resumida nesse parágrafo: o "homem" em geral é culpado e indigno devido ao tema agostiniano da queda, então ele deve buscar a redenção, a qual, paradoxalmente se ergue sobre o desprezo de si como condição de elevação) e como tal, deveria conduzir (num gesto de "decência") ao completo esgotamento da própria moralidade que ela pretende.

Aliás, afirma Nietzsche, há motivos de temer esse humano que odeia a si próprio, "pois seremos vítimas de sua cólera e de sua vingança. Cuidemos, então, de seduzi-lo para o amor a si mesmo" (A, 517). Só o amor a si pode desvincular o indivíduo de seu ódio e de sua cólera contra os demais, já que por não se amar, esse indivíduo, por sua honestidade, acaba encontrando motivos também para não amar o outro. O indivíduo se reconhece como bizarro porque não vislumbra em si senão a abstenção do egoísmo como forma de redenção. Nietzsche elide toda a construção da ética da compaixão: se ela insistir ainda no desprezo de si, não é digna de requerer o amor ao próximo como premissa de sua estrutura moral; se ela afirmar que é pela graça que o amor ao próximo deve existir, então deveria usar o mesmo argumento em relação ao indivíduo consigo mesmo e isso invalidaria, novamente, a pretensa premissa que lhe dá validade, ou seja, a culpabilidade do humano em geral como desprezível. Ao desvendar a incoerência dessa artimanha, Nietzsche explicita a engenhosidade e a falsa astúcia da moral que elegeu a compaixão como valor absoluto e fez todos os indivíduos (confortados sob o genérico conceito de "homem") iguais em sua dor.

\section{A falsidade do amor compassivo}


Essa "astúcia de serpente" (OS, 74), ao ser decifrada, exporia de que forma aquilo que a moral da compaixão chama de amor não passa de um "estratagema fundado sobre o desprezo" (KSA 8, 5[166], de 1875, p. 87). Aquilo que a moral cristã chama de amor, não passaria de um desprezo:

A artimanha mais sutil que dá ao cristianismo uma vantagem sobre as demais religiões é uma palavra: ele fala do amor. Convertendo-se assim, numa religião lírica (enquanto que em suas outras duas criações o semitismo brindou o mundo com religiões heroico-épicas). Há na palavra amor algo tão ambíguo, tão sugestivo, algo que fala à lembrança, à esperança, que ainda a mais humilde inteligência e o coração mais frio sentem algo da aureola desta palavra. (OS, 95) $\underline{3}$

O que faz do amor um sentimento ambíguo é o fato de que ele esteja fecundado pelo desprezo. Trata-se de um ardil que transformou esse sentimento num estimulante (porque conquista os indivíduos mais simples e dá ao cristianismo um requintado lirismo que atrai os corações e sequestra a inteligência) e, ao mesmo tempo, num equívoco (porque está fundado sobre o desprezo). É por sua ambiguidade e equivocidade que o amor compassivo teria se transformado em compaixão e piedade: “A piedade sincera em relação a si mesmo é o supremo sentimento ao qual o homem pode alcançar". A compaixão para consigo (selbst-Mitleid), enquanto centro da moral, está embasada num "falso conhecimento" do indivíduo em relação a si mesmo, ou seja, numa abnegação de si como pecador e merecedor de punição. É assim que esse sentimento se apresenta no asceta e no santo, como aqueles que conquistaram o autoconhecimento e por isso mesmo, a imagem que viram de si mesmo foi motivo de desprezo. Ora, esse autodesprezo faz com que os personagens da ética da compaixão sintam um profundo pesar e consternação em relação a si mesmos, unindo a esse sentimento de desprezo um segundo sentimento de comiseração e clemência. Então, segundo Nietzsche, o amor de si, quando somado ao desprezo de si, gera a compaixão para consigo mesmo.

Essa compaixão é caracterizada pelo filósofo como um sentimento superior já que só nos ascetas e nos santos ele é possível, porque apenas eles são capazes de amar e desprezar ao mesmo tempo. Entre os homens comuns, quem despreza a si não pode amar a si mesmo, nem pode amar o próximo aquele que não ama a si mesmo: "A mais perigosa desaprendizagem. - Começa-se por desaprender a amar os outros e termina-se por não encontrar nada mais digno de amor em si mesmo.” (A, 401). Ambos os sentimentos são ainda excludentes no caso geral. Os ascetas, ao contrário, tornam-se arautos da compaixão porque, no movimento de autodesprezo, aprendem a amar a si mesmos com compaixão. Por isso, o amor ao próximo, no caso do santo e do asceta, só pode ocorrer como resultado do desprezo que ele sente em relação a todos que o cercam: porque reconhece os demais 
como desprezíveis é que ele pode amá-los, já que o amor-compaixão é um resultado do desprezo ( $c f$. KSA 8, 9 [1], de 1875, p. 131). Por isso, num nível mais baixo, o que a moral da compaixão precisa ensinar é, primeiro, a desprezar e só assim pode erguer a sua prescrição à compaixão. Só quem despreza tem o direito de amar. Só quem reconhece a si mesmo e aos demais como indivíduos a serem desprezados é capaz de desenvolver o sentimento da compaixão, por reconhecer a pecaminosidade de todos os homens em geral. Todo amor ao próximo está constituído a partir da capacidade de reconhecimento do outro como alguém a ser desprezado: isso porque todo conhecimento e autoconhecimento de si e dos outros, na ética da compaixão, é entendido por Nietzsche como um processo de preterição, já que ao descobrir aquilo que é, o "homem" compassivo se vê como execrável e assim, sente indulgência e misericórdia em relação a si mesmo.

Esse sentimento de amor como compaixão, segundo Nietzsche, ganha expressão no modo como o Deus cristão (fundamento da faceta cristã da moral da compaixão), por si mesmo, ama os seus "filhos": ele tem misericórdia e compaixão, malgrado todo o pecado cometido pelo humano, porque sente um desprezo em relação à sua criatura. E é a compaixão de Deus pela situação do humano que possibilita a este suportar a existência terrível que pesa sobre si mesmo. Consequentemente, é esse lado terrível que aumenta a pena e a compaixão em relação a si mesmo. Afirmado como erro da razão e desvendado pela análise psicológica, também Deus como fundamento, é alvo da análise implementada por Nietzsche na sua tarefa de exoneração dos fundamentos da moralidade compassiva.

\section{A ascensão da compaixão como critério moral por excelência}

Ora, foi esse processo levou à ascensão da compaixão como único critério moral: “On n'est bon que par la pitié: Il faut donc qu' Il y ait quelque pitié dans tous nos sentiments - é o que diz a moral de hoje”, escreve Nietzsche no $\S 132$ de Aurora. A compaixão para consigo mesmo é vista agora como critério da moralidade e Nietzsche acredita que este um efeito do cristianismo na Europa (A, 132). Esse "efeito" pode, segundo Nietzsche, ser identificado pela presença desse ideal nas teses dos "livre-pensadores franceses, de Voltaire a Auguste Comte", e ainda "em Schopenhauer, em terras alemãs, e John Stuart Mill, em terras inglesas" os quais teriam dado "maior celebridade à doutrina das afecções simpáticas e da compaixão”. Para Nietzsche, esses ideais são ecos do estratagema cristão que se desenvolveu e espalhou pela Europa de forma grosseira "a partir da Revolução Francesa, e de todos os sistemas socialistas". É nisso, precisamente, que Nietzsche fundamenta a sua tese de que os ideais de igualdade e fraternidade se encontram erguidos sobre o terreno da doutrina da compaixão, no qual se 
supervaloriza a anulação do indivíduo e o seu sacrifício ao todo como supremo valor moral: "Agora parece que faz bem a todos ouvir dizer que a sociedade está em vias de adequar o indivíduo às necessidades gerais e que a felicidade e ao mesmo tempo o sacrifício do indivíduo está em sentir-se membro útil e um instrumento do todo". Se há alguma dúvida sobre como efetivar essa tarefa, diz Nietzsche: "surpreendente e bem soante, porém, é a concordância em exigir que o ego negue a si mesmo, até adquirir novamente, na forma da adequação ao todo, seu sólido círculo de direitos e deveres" (A, 132). Esse parágrafo, intitulado Últimas ressonâncias do cristianismo na moral, mostra como Nietzsche [1] entende as teorias da igualdade e da fraternidade como erguidas sobre o mesmo terreno da moral da compaixão e [2] que esse terreno é a negação e o desprezo de si mesmo, que leva a "uma debilitação e anulação do indivíduo". Numa passagem desse mesmo parágrafo Nietzsche revela claramente essa aproximação do ideal da igualdade na dor e da anulação do indivíduo no sentido social e moral-religioso: "Que o indivíduo de ações simpáticas, desinteressadas, sociais, de utilidade geral, seja visto agora como homem moral - é talvez o feito e a mudança mais amplos que o cristianismo produziu na Europa" $(\mathrm{A}, 132)$. Nota-se, assim, de que forma Nietzsche compreende o ideal "social" da igualdade como artefato da própria elevação desse modismo moral vigente.

Um pouco mais adiante nessa obra, ao criticar o clima mercantilista da sociedade moderna, Nietzsche destaca como resultado mais terrível dessa moral das "afecções simpáticas", o próprio cansaço do humano consigo mesmo, tantas vezes tematizado em suas obras:

Como devem ter pouca alegria consigo os homens de hoje, se uma tal tirania do temor lhes prescreve a lei moral suprema, se permitem, sem objeção, que lhes seja ordenado não olhar para si, mas ter olhos de lince para toda miséria, todo sofrimento de outra parte! Não estaremos, com esse descomunal propósito de limar todas as arestas e asperezas da vida, a ponto de transformar a humanidade em areia? Areia! Pequena, redonda, tensa, infinita areia! É este o seu ideal, arautos das afecções simpáticas? (A, 174).

Se essa "moda moral" fosse válida em tempos passados, afirma o filósofo, "grandes prodígios da moralidade antiga, como Epicuro, por exemplo" que nada sabia "da glorificação do pensar em outros, do viver para os outros" teriam de ser "chamados imorais, pois lutaram com todas as forças por seu ego e contra a empatia com os outros (sobretudo com seus sofrimentos e suas fraquezas morais)" (A, 131). A expressão "moda moral [moralischen Mode]" evoca a temporalidade desse valor, com o fim de mencionar a sua pretensão em elevar-se como valor absoluto e definitivo: nem sempre foi assim e isso pode mudar - é o que se lê por trás dessa afirmação. Trata-se da crítica desse "modismo moral" que alçou a abnegação de si como valor absoluto, sob o custo do enfraquecimento 
do ser humano: "Em nossos tempos se desconfia de todo aquele que crê em si mesmo; outrora ele bastava para fazer crer em si. A receita para ganhar crédito agora reza: 'não tenhas atenção contigo mesmo! Se queres pôr tua opinião sob uma luz digna de crédito, coloque fogo na tua própria choupana (Hütte)'”' (A, 319).

Nos parágrafos subsequentes do livro II, de Aurora encontram-se esboçados os principais argumentos que tem a pretensão de indicar a incoerência e a imoralidade da assim pretendida moral da compaixão. No § 133 Nietzsche mostra como a compaixão não é um "pensar no outro" de forma desinteressada, mas uma manifestação "fortemente inconsciente" que se ergue como apoio à nossa impotência ou covardia, evocada pelo outro que clama a nossa ajuda. Ou seja, qualquer ajuda a outrem não é realizada de forma desinteressada, mas por medo de que a nossa honra seja diminuída perante os demais ou porque o acidente do outro mostra a nossa vulnerabilidade. $O$ ato de ajuda é um ato inconsciente de egoísmo, portanto, quase como um "sutil" ato de "legítima defesa". Segundo Nietzsche, quando pretensamente ajudamos os outros, "é equivocado chamar o sofrimento [Leid] que nos causa tal visão, que pode ser de tipo bastante variado, de compaixão [Mit-leid], pois em todas as ocasiões é um sofrimento do qual está livre aquele que sofre à nossa frente: ele nos é próprio, como é próprio dele o seu sofrimento. Mas é apenas deste sofrimento próprio que nos livramos ao praticar atos de compaixão" (A, 133). Ou seja, a compaixão não é uma afecção pelo outro, mas meramente uma forma de socorro à dor que é própria do indivíduo que assiste à dor do outro. Se há algum tipo de ajuda, ela é menos para apoiar o outro em sua dor (algo que lhe é próprio, ou seja, não pode ser conhecido por outrem) do que para se livrar da dor de ver o outro sofrer. Além disso, Nietzsche mostra como o sofrimento do outro, em contraposição, pode causar prazer ao indivíduo que vê o outro sofrendo: "o prazer surge à visão de um contraste à nossa situação, à ideia de que podemos ajudar se quisermos, ao pensar no louvor e na gratidão, caso ajudássemos; surge da atividade mesma de auxílio, enquanto o ato é bem-sucedido e, como algo de êxito progressivo, em si mesmo dá alegria a quem o realiza" (A, 133). Nietzsche pretende mostrar que por detrás desse sentimento tido como tão nobre e supremo, escondem-se inúmeras possibilidades de interpretação que não são mais do que manifestações de egoísmo, algo que fora esquecido pelos arautos da moral da compaixão justamente porque esses não experimentaram esse sentimento ("faltou precisamente, a quem incensou a compaixão [...] experiência bastante nesse âmbito da moral").

A aplicação do método psico-fisiológico de análise da moralidade, característico da estratégia do filósofo nesse segundo período, leva Nietzsche nesse momento a afirmar que Schopenhauer conheceu mal e descreveu precariamente a compaixão porque não soube experimentá-la, atribuindo à sua descrição um mero sentido "imaginativo". Traçando as 
características que distinguiriam os "homens sem compaixão daqueles compassivos" Nietzsche explicita como nos primeiros falta "a excitável imaginação do medo, a fina capacidade de pressentir o perigo", "em geral estão mais acostumados a tolerar a dor", neles "a brandura do coração é uma condição penosa", sendo "uma espécie de egoístas diferente dos compassivos" (A, 133). Mesmo assim, não é possível, afirma Nietzsche explicitando o tempo grego no qual esse valor de abnegação de si em favor do outro não era vigente - chamar ao "homem" compassivo de bom e ao não compassivo de mau. Essa não é "senão uma moda moral que tem seu tempo: assim como a moda inversa também teve seu tempo, um tempo demorado". Essa epocalidade da moral da compaixão é que serve de referência para a possibilidade de sua superação.

Nietzsche, aos poucos, desvenda o estratagema da compaixão e tenta comprovar a sua ineficácia e tartufaria em sentido moral. Ela não seria mais do que "uma fraqueza, como todo abandono a um afeto que prejudica" (A, 134). Porque "faz crescer o sofrimento no mundo" e a própria necessidade de que haja sofrimento e desprezo de si mesmo, a compaixão torna-se prejudicial à vida, ainda que aqui e ali possa se apontar algum caso de "sofrimento diminuído ou suprimido graças à compaixão". No geral, ela é um prejuízo que, caso predominasse "por um só dia, imediatamente pereceria toda a humanidade". Ao descobrir na compaixão uma "fonte de prazer" os homens compassivos da moral prendem-se a todo custo a um sentimento que, em si, "tem caráter tão bom quanto qualquer outro impulso" (ou seja, não acarreta nenhum juízo de bem e mal), mas que, hipertrofiado, provoca um desequilíbrio entre os impulsos e, assim, se tornaria, como entre os gregos, um "doentio afeto periódico". Por isso, o "médico" da humanidade deve "ser muito cauteloso" com esse sentimento, porque ele "paralisa os instantes decisivos": "Quem quiser fazer a experiência de, por algum tempo, ceder propositalmente às oportunidades de compaixão na vida prática e sempre manter no espírito a miséria toda que se apresenta à sua volta, ficará inevitavelmente doente e melancólico" (A, 134).

"Oferecer compaixão equivale a desprezar" (A, 135): Nietzsche afirma que entre os "selvagens" sentir-se objeto de compaixão é algo desprezível e que ver sofrer alguém desprezível não causa prazer algum. Ao contrário, ver sofrer quem é forte e suporta a dor com valor e orgulho, isso é um sinal de força e pode causar "o maior dos deleites". Matar o indivíduo que sofre se transforma, para esse selvagem, num gesto de honra e de admiração. Se, ao invés de matar o que sofre, alguém chorasse e se mostrasse compassivo em relação a ele, isso faria dele um ser desprezível e "ao invés da admiração, apareceria a compaixão". Nesse parágrafo, Nietzsche recorre à oposição "admiração" [Bewunderung] e "compaixão" [Mitleiden]. O primeiro é o sentimento típico dos espíritos livres; o segundo um sentimento dos espíritos cativos que partilham a vida como dor e sofrimento. 
É nesse sentido que a compaixão será analisada como um impulso hipertrofiado no indivíduo fraco que não se arrisca e prefere fugir da vida pela via da negação da Vontade. Se toda a atividade intelectual, escreve Nietzsche no $\S 136$, do segundo livro de Aurora, for dirigida, como o fazem os hindus, ao "conhecimento da miséria humana", então a compaixão se torna um antídoto contra o suicídio, já que ela traz paz e possibilita "pequenas doses" que fazem "provar a superioridade": "ela nos distrai de nós, enche o coração, afasta o medo e a rigidez, incita à palavra, aos lamentos e atos". Trata-se de um sentimento que gera "relativamente uma felicidade" - "E a felicidade, seja ela qual for, traz luz, ar e liberdade de movimento". Assim, Nietzsche aproxima a moral da compaixão daquilo que será tematizado posteriormente, de forma não menos paradoxal, em Para $a$ genealogia da moral através da análise do ideal ascético - e que encontra a sua formulação na paradigmática afirmação de que "o homem preferirá ainda querer o nada a nada querer..." (GM, III, 28).

No parágrafo seguinte (137) Nietzsche lança mão do conceito de Erlebnisse para perscrutar o ideal da compaixão. Partindo da noção de que as vivências de cada indivíduo são incomunicáveis, Nietzsche critica a pretensão da moral da compaixão em exigir que um indivíduo adentre no misterioso mundo das vivências do sofrimento de um outro, provocando aquilo que nesse fragmento será chamado de processo de "duplicação do 'Eu'":

\footnotetext{
Observar nossas vivências com o olhar com que costumamos observá-las quando são vivências de outros - isso tranquiliza bastante e é um remédio aconselhável. Mas observar e acolher as vivências dos outros como se fossem nossas - a exigência de uma filosofia da compaixão -, isso nos destruiria em pouco tempo: apenas façam a tentativa e deixem de fantasiar! (...) Já a compaixão como princípio de ação, com a exigência de sofrer com o infortúnio do outro como ele mesmo, implicaria que o ponto de vista do Eu, com seu exagero e excesso, também se tornasse o ponto de vista do outro, do compassivo: de forma que teríamos de sofrer ao mesmo tempo com o nosso Eu e o do outro, e nos sobrecarregaríamos voluntariamente de um duplo contrasenso, em vez de tornar mais leve o peso do nosso. (A, 137)
}

O que torna essa hipertrofia do impulso compassivo algo prejudicial ao indivíduo é que ele passa a sofrer não apenas com a sua dor, mas com a dor do outro, de forma a elevar o peso da exagerada e excessiva ideia de um "eu" com o peso do sofrimento do outro. É assim que a ética da compaixão, ainda que ocasionalmente apareça como alívio da vida, no fundo leva a um aprofundamento na dor e no sofrimento, ao que a torna ainda mais doente e pesada. A vivência de cada indivíduo, apenas racionalmente transposta a um outro faz com que, pela via da consciência, o sofrimento se torne denso demais e a vida algo 
indesejado. Mais uma vez, a ética da compaixão não poderia levar a outro caminho, senão à moral da negação e fuga da vida.

A duplicação do "eu", nesse parágrafo, não deve ser entendida como uma aceitação de alguma pretensa precedente unidade do indivíduo. Ao contrário, a ética da compaixão, por acreditar nessa unidade, acaba por fabricar, com suas próprias mãos, um processo de divisão ${ }^{4}$ do indivíduo que aqui é descrito como um processo de duplicação: se na moral em geral o indivíduo é apresentado como dividido, na moral da compaixão ele é duplicado em seu sofrimento porque se lhe exige que compartilhe a dor do outro. Essa duplicação é causada pela partilha dessa dor que ergue como que uma ponte sobre o fosso das vivências próprias de cada indivíduo. É assim que o amor, após identificar no outro alguém que sofre, se transforma em "algo essencial" (A, 138) que causa uma sensação de igualdade. Aí nasce o desejo de retribuição ao sofredor e isso causa um prazer com sua dor - um prazer que adquire sua superioridade quando o sofredor vê que provoca sofrimento no seu espectador:

O fato de poder retribuir nos proporciona uma grande alegria e elevação. Buscamos adivinhar o que suaviza a sua dor, e lhe damos isso; se quer palavras de consolo, olhares, atenções, presentes, serviços - lhe damos isso; mas sobretudo: se nos quer sofrendo com o seu sofrimento, damo-nos por sofredores, mas em tudo isso tendo o prazer da gratidão ativa: que é, em suma, a boa vingança. Se não quer e não aceita absolutamente nada de nós, afastamo-nos frios e tristes, quase doentes: é como se nossa gratidão fosse rejeitada. (A, 138)

A compaixão evoca no compassivo a vingança porque exige que o outro sofra com seu sofrimento. É nesse processo, no limite, que ela se torna uma Mitleid, ou seja, um compartilhar de dor, uma espécie de vingança que não passa de uma forma de provocar também o sofrimento do outro e isso, concomitantemente, gera um prazer. A rebuscada argumentação de Nietzsche nesse parágrafo faz ver que há na relação de compaixão também uma relação de poder. Todo "louvor e censura" (título do parágrafo seguinte - 140) é uma manifestação desse poder que faz do outro um "bode expiatório", "uma vítima dos fracos, humilhados, abatidos, que de algum modo querem provar a si mesmos que ainda têm força" (A, 140).

O processo de compartilhamento do sofrimento alheio é descrito por Nietzsche como tendo seu fundamento na pergunta sobre o motivo do sofrimento do outro: "por que ele está aborrecido?" é a pergunta fundante dessa relação compassiva que está embasada numa empatia com o sofrimento. E para que se pretende conhecer o sofrimento do outro? Ora, para "nos aborrecermos pelo mesmo motivo", responde ironicamente Nietzsche no $\S$ 142 de Aurora. Mesmo quando não se faz a pergunta pelo motivo, gera-se um sentimento conforme os "efeitos" que a dor do outro provoca num indivíduo, associando movimento e 
sensação de tal forma que um quase que "vivencia" essa dor do outro. O humano, como "a mais temerosa das criaturas, devido à sua natureza frágil e refinada, tem no seu temor o mestre dessa empatia”. Então, é o medo, esse instinto natural que remonta aos primórdios da criatura-homem, que possibilita essa empatia rápida com o sentimento do outro: " $\mathrm{A}$ alegria e o agradável assombro, e enfim o senso do ridículo, são filhos temporãos da empatia, e irmãos bem mais novos do medo". É pelo medo despertado pela visão do sofrimento alheio que faz o indivíduo temer esse mesmo sentimento, que ele desenvolve essa empatia com a dor do outro. Nietzsche aqui, aproxima, portanto, a compaixão do estrito sentido do conceito de empatia: o indivíduo sente em si o que sentiria caso estivesse na situação e circunstâncias experimentadas pelo outro. E o que provoca esse sentimento é o medo de que isso seja realmente possível, ou seja, que ele venha a sofrer como o outro está sofrendo.

\section{O "grande perigo" da compaixão}

No aforismo 271 de $A$ Gaia Ciência Nietzsche escreve: "Onde estão seus maiores perigos? - Na compaixão." Mas de que forma esse sentimento poderia ser prejudicial? Tratado como um impulso, a compaixão é vista por Nietzsche como algo perigoso quando excessivo, capaz de tornar o mundo "insuportável” caso simplesmente se lhe dobrassem as

forças, por exemplo: "Supondo que o impulso de apego e cuidado em relação a outros (a 'afecção simpática') fosse duas vezes mais forte do que é, as coisas não seriam suportáveis na Terra" (A, 143). Assim, por um lado, caso alguém dedicasse de fato todo o cuidado e se empenhasse em relação ao outro com todo o excesso de diligência que dedica a si mesmo, isso tornaria o "próximo" alguém a ser temido, a tal ponto que esse sentimento (a afecção simpática) seria recoberto "dos mesmos nomes ruins que agora aplicamos ao egoísmo": ou seja, ele se tornaria insuportável. Deixando-se levar "pelos lamentos e dores dos outros" $(\mathrm{A}, 144)$ a um indivíduo poderia se tornar insuportável todos os seus fardos existenciais, e de tal forma seria ele entristecido, que não teria outro motivo senão fugir e negar a existência (note-se como aqui Nietzsche de fato tenta explicar o processo pelo qual Schopenhauer teria forjado a sua moral da negação da vontade de viver).

No fim, a esse amor chamado compaixão, não estão vedadas as premissas egoístas, conforme ele mesmo pretende. Toda compaixão, segundo Nietzsche é prejudicial, sobretudo por tentar excluir o isomorfismo existente entre ela e o egoísmo - ambos impulsos vitais. O que se busca no amor - mesmo no amor compassivo - é sempre "um indivíduo que sirva a seu propósito": "Aquele está oco e quer ficar cheio, esse está repleto e quer esvaziar-se" (A, 145): é para esses dois processos que ambos dão o nome de amor. 
Mas no primeiro - típico dos compassivos - há uma carência e uma falta demasiado aflitas, enquanto no segundo caso há um luxo, um derramamento, uma riqueza que quer irromper como amizade ${ }^{5}$. Como luxo, a amizade está baseada no poder sobre si mesmo e na conquista que o indivíduo faz de si: é por esse poder que ele confere um direito próprio de, inclusive, compadecer-se consigo. O amigo não se compadece porque isso se torna desnecessário, conforme escreve Nietzsche no parágrafo 437 de Aurora:

Quem realmente possui a si mesmo, isto é, conquistou definitivamente a si, vê doravante como privilégio próprio castigar-se, perdoar-se, compadecer-se de si mesmo: ele não precisa concedê-lo a ninguém, mas pode livremente passá-lo às mãos de outro, de um amigo, por exemplo - mas sabe que assim confere um direito, e que direitos podem ser conferidos apenas desde que se possua poder.

Mas ainda, ironicamente, afirma Nietzsche, aquele que ama por transbordamento e aquele que ama por falta pretendem que o "amor deveria ser algo não-egoísta". Nada mais impraticável! O problema é que o amor se tornou uma questão muito valorizada e pouco experimentada: "De modo geral, as pessoas falaram do amor com tanta ênfase e adoração porque tiveram pouco dele, nunca puderam saciar-se desse manjar" (A, 147). Assim, Nietzsche denuncia a falência do ágape na ética da compaixão e o anúncio da philia como necessária.

A elevação da compaixão como requisito moral por excelência faz com que ela pretenda uma negação do indivíduo em função de uma afirmação do direito do próximo. Para Nietzsche, toda a moral da abnegação que coloca o outro como divisa moral das ações e que faz com que todas as decisões sejam tomadas em função dela não passa de uma "moral estreita e pequeno-burguesa" (A, 146). O outro como divisa se apresenta enquanto limite, porque Nietzsche requisita a possibilidade de que os fins morais estejam para além dessa fronteira (e que poderia incluir a geração do sofrimento do outro em função de algo maior do que ele) ${ }^{6}$. Se for preciso tratar o próximo como a si mesmo, então não seria insano desejar que ele fosse "sacrificado" em função de algo maior, como muitas vezes faz o livre-pensador consigo mesmo: "Supondo que tivéssemos o sentido do sacrifício em relação a nós: o que nos proibiria de sacrificar conosco o próximo?" Ou ainda, pergunta Nietzsche: "por que não deveriam alguns indivíduos das gerações atuais serem sacrificados às gerações futuras?” (A, 146). Muito do sofrimento, dor e desespero, poderia ser entendido e aceito como necessários para a construção de algo que esteja para além desse indivíduo que é o outro. Então, o outro não pode ser considerado a medida absoluta da moral e nem sequer a compaixão para com ele o fundamento da moralidade tal qual pretendeu Schopenhauer: a vida tem objetivos que podem bem ser pensados acima de um indivíduo. Em busca da vitalidade do poder humano, o Nietzsche dessa análise requisita a presença 
das teses que fazem do "homem" uma ponte para o além-do-humano, para o qual ele deve sacrificar-se e para quem o próximo não passaria de uma fraca antecipação, um estágio preparatório: "Enquanto nós, através do sacrifício - no qual estão incluídos nós e os próximos - fortaleceríamos e elevaríamos mais alto o sentimento geral do poder humano, supondo que não conseguíssemos mais. Mas isto já seria um positivo incremento da felicidade." (A, 146).

A felicidade, para o filósofo alemão, está acima da felicidade do outro, da garantia das condições para que o outro seja feliz: acima disso, estaria a felicidade que nasce da vitalidade do poder humano que é incrementado. É essa uma felicidade mais benéfica e a sua negação faria do próximo, um prejuízo moral. Para Nietzsche, a ideia moderna de felicidade se contrapõe à afirmação individual - e por isso mesmo, se constitui como equívoco, já que "ao indivíduo, enquanto busca sua felicidade, não se deve dar prescrições sobre o caminho para a felicidade: pois a felicidade individual brota de leis próprias, desconhecidas de todos, e preceitos externos podem apenas inibi-la, impedi-la" (A, 108). Ou seja, a felicidade é uma conquista individual que não pode ser pretendida por qualquer prescrição moral, porque, segundo Nietzsche, “os preceitos chamados de 'morais' são, na verdade, dirigidos contra os indivíduos" (A, 108). Ao restituir a importância do júbilo consigo mesmo, Nietzsche o faz por acreditar que só assim se obterá como resultado, uma proteiforme conjuntura de forças que só fazem sentido no indivíduo e que, por isso mesmo, fogem às configurações morais orientadas por preceitos, imperativos ou deveres exteriores.

\section{Considerações finais}

A conclusão do livro segundo de Aurora não poderia ser outra: "Se apenas forem morais, como se definiu, as ações que fazemos pelo próximo e somente pelo próximo, então não existem ações morais" (A, 148). Nietzsche chega à conclusão de que a moral não passa de "efeitos de alguns erros intelectuais", denunciando a hipertrofia da compaixão como resultado da separação das chamadas "ações "egoístas"” e as "não-livres". Essa hipertrofia seria combatida com uma nova reunião desses impulsos que embasam o que se chamou de bem ou de mal em termos morais: "Se agora tornamos a juntá-las a estas, como temos de fazer, diminuímos certamente o seu valor (o sentimento de seu valor), e isso abaixo da medida razoável, pois as ações 'egoístas' e 'não-livres' tiveram avaliação muito baixa até o momento, devido à suposta diferença intrínseca e profunda." (A, 148).

Por fim, se houvesse algum acordo sobre a benevolência e a beneficência do ser humano como próximos da bondade, então isso deveria ser praticado primeiramente em relação a si mesmo: 
Estejamos de acordo, neste nosso tempo, em que benevolência e beneficência constituem o homem bom; vamos somente acrescentar: "pressupondo que ele antes seja benevolente e beneficente consigo mesmo!" Pois sem isso ele foge de si, odeia a si, prejudica a si mesmo - ele certamente não é um bom homem. Então ele apenas salva-se de si mesmo nos outros: que esses outros cuidem para que não fiquem mal, por mais bem que ele aparentemente lhes queira! - mas precisamente isto: fugir do ego e odiá-lo, e viver no outro, para o outro - foi até agora considerado, de forma irrefletida e muito confiante, "altruísta" e, portanto, "bom". (A, 516)

A fuga de si mesmo no outro é a característica da moral da compaixão, mas isso representa um "salvar-se de si nos outros". A proposta de Nietzsche segue em via contrária:

\footnotetext{
Mas nossa contrapartida é que restituímos aos homens a boa coragem para as ações difamadas como egoístas e restauramos o valor das mesmas - roubamos delas a má consciência! E, como até hoje foram as mais frequentes, e em todo o futuro continuarão a sê-lo, retiramos a todo o quadro das ações e da vida a sua má aparência! Não mais se considerando mau, o homem deixa de sê-lo. (A, 148)
}

A base da crítica de Nietzsche é o processo de destituição daquilo que se rotulou como associado à má-consciência, recuperando no indivíduo aquilo que é seu, ou seja, não apenas negando uma parte de seus impulsos em função da elevação de outros mais fracos e doentios, mas restituindo-lhe a integridade perdida na moral. Contra a duplicação e a divisão do indivíduo, agora Nietzsche o pensa em sua integralidade: a partir do júbilo e do contentamento consigo mesmo. Por não se considerar mau e desprezível o humano deixaria de sê-lo, afirma Nietzsche.

\section{Referências bibliográficas}

NIETZSCHE, Friedrich. Além de Bem e Mal. Prelúdio a uma Filosofia do Futuro. Trad. Paulo César de Souza. São Paulo: Cia. das Letras, 2. ed., 2002.

NIETZSCHE, Friedrich. Aurora. Reflexões sobre os preconceitos morais. Trad. Paulo César de Souza. São Paulo: Cia. das Letras, 2004.

NIETZSCHE, Friedrich. Genealogia da Moral. Uma polêmica. Trad. Paulo César de Souza. São Paulo: Cia. das Letras, 2002.

NIETZSCHE, Friedrich. Humano, Demasiado Humano. Um livro para espiritos livres. Vol. I. Trad. Paulo César de Souza. São Paulo: Cia. das Letras, 2000. (Vol. I e II) 
NIETZSCHE, Friedrich. Humano, Demasiado Humano. Um livro para espíritos livres. Vol. II. Trad. Paulo César de Souza. São Paulo: Cia. das Letras, 2008.

NIETZSCHE, Friedrich. Sämtliche Briefe. Kritische Studienausgabe (KSB). Herausgegeben von Giorgio Colli und Mazzino Montinari. München/Berlin/New York: dtv/Walter de Gruyter \& Co., 1986. (8 Bänden).

NIETZSCHE, Friedrich. Sämtliche Werke. Kritische Studienausgabe (KSA). Herausgegeben von Giorgio Colli und Mazzino Montinari. München/Berlin/New York: dtv/Walter de Gruyter \& Co., 1988. (15 Einzelbänden).

SCHOPENHAUER, Arthur. O mundo como vontade e como representação. $1^{\circ}$ Tomo. Tradução, apresentação, notas e índices de Jair Barboza. São Paulo: Editora UNESP, 2005.

. Sobre o fundamento da moral. Trad. Maria Lúcia Cacciola. São Paulo: Martins Fontes, 1995.

\section{Notas}

${ }^{2}$ Para as referências das obras de Nietzsche, usamos as siglas convencionais: HH I (Humano, Demasiado Humano, vol. I); OS (Humano, Demasiado Humano II: Opiniões e sentenças diversas); AS (Humano, Demasiado Humano II: O andarilho e sua sombra); A (Aurora); GC (A Gaia Ciência); KSA (Sämtliche Werke. Kritische Studienausgabe - edição crítica em 15 volumes organizada por Giorgio Colli e Mazzino Montinari - a sigla será seguida do número do volume, número do fragmento, ano de escrita e página). Para O mundo como vontade e como representação, de Schopenhauer, usaremos a sigla MVR, seguida da página da tradução de Jair Barboza.

${ }^{3}$ Num fragmento preparatório desse texto (KSA 8, 17[19], de 1876, p. 299) se lê uma associação dessa "artimanha" a Platão: "A artimanha mais sutil do cristianismo foi falar de amor, como também o foi a de Platão. Há nela algo tão ambíguo, com tal poder de convocatória e tão evocador, que ainda a mais humilde inteligência sente a aureola desta palavra: a mulher mais anciã e o homem mais racional agradecem ao amor os momentos mais nobres e desinteressados de sua vida"

4 “Na moral o homem não trata a si mesmo como individuum, mas como dividuum" (HHI 57)

${ }^{5}$ Nietzsche esboça, nesse período de sua produção filosófica, a hipótese de que só na amizade sentimentos como benevolência, empatia ou mesmo simpatia ganham legitimidade e autenticidade e, nessa medida, a amizade, integrando a compaixão, forneceria as bases de uma ética superior porque representaria uma tentativa de superação do pretenso antagonismo entre indivíduo e cultura: “A congratulação faz o 'amigo' (o que se congratula - Mitfreunder), a compaixão faz o companheiro de penas. - Uma ética da compaixão precisa do complemento de uma superior ética da amizade.” (KSA 8, 19[9], de 1876, p. 333)

${ }^{6}$ Com essa tese Nietzsche se contrapõe ao fundamento da moral kantiana que constitui aquilo que o filósofo de Könninsberg chamará de Reino dos Fins, no qual cada homem teria valor em si mesmo e, pela autonomia da vontade, imporia sobre si mesmo as leis morais. O conceito orienta a Metafísica dos costumes e o texto sobre a Religião nos limites da mera razão, pelos quais Kant busca a construção da comunidade jurídica e ética. Para o autor, há uma "ligação sistemática, por meio de leis comuns, tanto de diversos seres racionais enquanto fins em si como também dos próprios fins que cada ser racional se dê" (KANT, 1988, p. 79), ou seja, os seres racionais não constituem uma pluralidade, mas uma totalidade na medida em que estão unidos sistematicamente por leis. Como membro de um Reino dos Fins, o ser humano é ligado ao outro pelo cumprimento dessa lei comum a todos. "A teleologia considera a natureza como um reino dos fins; a moral considera um possível reino dos fins como um reino da natureza. Acolá o reino dos fins é uma ideia teórica 
para explicar o que existe. Aqui é uma ideia prática para realizar o que não existe mas que pode tornar-se real pelas nossas ações ou omissões, e isso exatamente em conformidade com esta ideia.” (KANT, 1988, p. 80)

Recebido: $10 / 12 / 10$

Received: 12/10/10

Aprovado: $31 / 12 / 10$

Approved: 12/31/10 